\title{
Where to find nature? Connecting with nature in urban and non-urban areas in southwestern France
}

\author{
Isabelle Duvernoy $(\mathbb{D} \cdot$ Mélanie Gambino $\mathbb{C}$
}

Accepted: 9 February 2021 / Published online: 6 March 2021

(C) The Author(s), under exclusive licence to Springer Nature B.V. part of Springer Nature 2021

\begin{abstract}
Visiting natural areas is considered an important factor of well-being. Along with urbanization, an extensive literature has developed that examines the presence of natural areas in urban settings for the benefit of urban dwellers. However, little is known about how much people perceive the presence of nature in different types of areas (such as city or countryside) and the places where they seek this presence. In this article, we present a study of these two questions through the interviews of 52 inhabitants from 13 municipalities (cities, suburbs and other areas) in Southern France. Through the quotes where nature was mentioned, we studied their perceptions of its presence in the different categories of areas they distinguish (city, countryside, mountain, seaside), as well as the various places where they established a contact with nature. Our results highlight the ranking of the areas where such a connection is pursued. Their interviews show both the importance of the residence itself as a place of contact with nature, and of the mobility patterns that make people feel closer to nature, such as relocation, multiple residences, short outings and longer trips. This qualitative study
\end{abstract}

I. Duvernoy ( $\square)$

UMR AGIR, Université de Toulouse, INRAE,

31320 Castanet-Tolosan, France

e-mail: isabelle.duvernoy@inrae.fr

M. Gambino

UMR LISST-DR, Université de Toulouse, Toulouse,

France attempts to enrich the vision of the human connection with nature beyond the present focus on such connections in the city.

Keywords Connection with nature - Natural areas . Residence · Urban · Rural - Qualitative data analysis

\section{Introduction}

Mathieu (2017) highlights the fact that the connection with nature is a major component of modern life. People's awareness and increasing consciousness of rapid environmental changes have led to a general transformation in the experience of nature (Kalaora 2001; Pickel Chevalier 2014). Access to natural areas and contact with nature were previously associated with non-urban areas (Tjallingii 2000). They are now also envisaged in cities, in a global context of urbanization, already especially high in Europe, where the part of the population living in cities reached $74 \%$ in 2018 (United Nations 2018). City planning now includes land conservation schemes and recognized natural areas (Arnould et al. 2011; Banzo 2009; Hess and Salomon Cavin 2015; Kowarik 2013), whereas nature reserves had long been relegated to non-urban settings (Mormont 1987).

In that context, Klaniecki et al. (2018) suggested that the geographical dimension of people's 
connection with nature deserves much more attention. Their own study focused on the scales, from local to global, at which people perceived such connections. In this article, we intend to highlight two other geographical features (Jessop et al. 2008). One is the very places where such connections are pursued. Indeed, if the current literature focuses on people's connections with nature close to their urban residence (see, for example, Schipperijn et al. 2010), little is known about the variety of locations where people seek the presence of nature. Do urban residents go only to places nearby? Would they rather go to the countryside? Do they? And do people living in the countryside imagine that nature can be found in cities? Thus, we first need to address the "areal differentiation" (Jessop et al. 2008) people take into consideration to situate nature, i.e., the classification of areas into different interrelated categories. One such classification differentiates cities from other types of areas such as countryside. Traditionally, one of the central criteria of this classification of areas has been the absence or the presence of nature (Kowarik 2013; Tjallingii 2000). While such categories have undergone deep changes, they still remain an important part of lay discourses. Another objective of this paper is to then see if and how people link these categories with the presence/ absence of nature today.

This introduction section is dedicated to exploring the recent literature on the study of the human-nature connection and how its geographical dimension has been examined. We will then consider the link between nature and the depiction of different categories of areas. The rest of the article is based on an empirical study of the variety of lifestyles at the regional scale of southwestern France, considering four intertwined topics: the residence; the perception of the differences between cities and other areas; the mobility patterns for jobs, services and leisure; and the places and types of areas where people find nature. The second section presents this material and our methodology in order to analyze people's connections with nature. The third section introduces our results according to two main questions: Do people differentiate types of areas on the basis of the presence/ absence of nature? Do they frequent several places to find a contact with nature? We compare and discuss the responses to these two questions in the final section.
The question of place in studying the connection with nature

The term "nature" cannot be clearly defined nor does it mean the same thing for everybody. Some authors even emphasize its fuzziness: it is an "umbrella term" (Cadieux 2011, p. 352) that can elicit various images (Emelianoff 2016). Several scientific fields contribute to the literature on the connection with nature, making it hard to find a single accepted definition for the term. Nevertheless, two recent reviews in the literature identify increasing forms of connection with nature. Zylstra et al. (2014, p. 125) depict a continuum comprising information about nature, contact with nature (generally through structured outdoor activities), affective experiences (that may also involve outdoor activities but that are less structured by a goal or timing, such as immersion in nature), and commitment to nature. Ives et al. (2017) distinguish five types of connections to nature: material (extraction of natural resources), experiential (such as taking a walk in a forest), philosophical, emotional and cognitive, the last one implying values, beliefs and awareness. In the two typologies, the experience of nature can entail material practices and/or cognitive representations (Øian 2013), explaining why the notion of "nature" can vary deeply from one person to another, depending on the way he or she connects to nature. As for the reasons for such differences in the types of connections to nature, some authors emphasize social factors such as the cultural or the social background of the person (Buijs et al. 2009; Øian 2013; Sahuc 2010), or the transmission by collective practices (Zylstra et al. 2014), notably during childhood (Colléony et al. 2017; Sahuc 2010). Others, however, highlight the areas where people live that might offer different opportunities for contact with nature (Zylstra et al. 2014).

Ives et al. (2017) identified three different ways to study the connection with nature, two of which consider different geographical dimensions:

(i) The first one addresses people's cognitive and philosophical connections that could result in different images of nature itself and the way to connect to it. For instance, Buijs et al. (2009) showed that various images of nature coexist in the Netherlands. Building on ecocentric values, one image emphasizes the independence of nature and the need to 
minimize its management. Another, building on anthropocentric values, adopts a functional view of nature and positively considers its intensive management for human needs.

(ii) The second one focuses on the assessment of people's preferences for some landscapes over others, generally through the quantitative study of respondents' rankings of pictures (Colléony et al. 2017; Khew et al. 2014). For instance, Kaplan and Austin (2004) concluded that residents looking for "natural" places valued less manicured, landscaped and mowed areas than forests and wetlands. Buijs et al. (2009) showed that the contrasted images of nature they identified in the Netherlands resulted in preferences for different types of landscapes according to the intensity of their management.

(iii) The third one consists in studying people's experiences in one natural area, or how the experiences of the same place by different groups of people might conflict. As an example, this could include the cultural differences between local residents and tourists involved in the same outdoor activity in the same place (Øian 2013), or the differences between working and middleclass activities in a natural area, the first ones based on acting and the second ones on watching (Sahuc 2010).

The geographical imagination of such studies then seems dedicated to the preferred type of landscape (ii), or to the experience in one place (iii). Yet, the places where people live, where they go, how their experience of nature is distributed and ranked between several places, might not be sufficiently taken into consideration. To think about the opportunities of a contact with nature offered by different places, we now address the traditional divide between cities and other areas in terms of their historical association with the notion of nature.

Where is nature? Features of opposition and intertwining in the classification of geographical areas

The classification of geographical areas into different categories of human settlement has a long history. In the Latin and Greek traditions, such a classification was based on the opposition between humanity, and its human settlements and nature (Berque 2011). The traditional discourse still opposes the city and nature today (Kowarik 2013; Tjallingii 2000). From this point of view, the city is defined by its ability to master natural phenomena and by its mineral aspect (Blanc 1997a, b). When present, nature in the city seems less real, even factitious (Glatron et al. 2012), since it is traditionally associated with minimal human intervention (Kowarik 2013). The countryside has been depicted as an intermediate stage between cities and the wilderness, between artificial and natural places (Berque 2011). However, the conceptual links between the countryside and nature have increasingly changed over time. According to Berque (2011), the conceptual limit between human territories, including farmed land and the wilderness, became less clear during the European Renaissance when both countryside and farmed landscapes were portrayed as being a part of nature. Being in the countryside makes it possible to be closer to nature (Kaplan and Austin 2004). In the North American context, Smith (2008) identifies the opposite phenomenon in the eighteenth and nineteenth centuries, when the successive forms of anti-urbanism dissociated nature and the countryside, and valorized nature as being ontologically different from society, be it urban or rural.

Such distinctions between geographical areas have been challenged since the 1950s by: (i) the urbanization and the disappearance of agrarian societies in Western countries; (ii) the transformation of urban settings toward low-density cities (suburbanization in the form of ex-urbanization (Cadieux 2011), edge cities); and (iii) regional dynamics that associate cities and less dense areas. The combination of these three phenomena has blurred the formalized distinction between urban and rural areas. Yet, these categories have remained present until now in lay discourses (Blanc 1997a, b; Tjallingii 2000). They have also maintained their relevance for organizing social practices (Blanc 1997a, b; Mathieu 2017; Øian 2013), e.g., dwelling choices. The phenomenon known as "anti-urbanism", the choice to live outside the city, is a criticism of urban life and its "dominant economic universe" (Mormont 1987, p. 11); it strongly opposes the city to other types of areas (Halfacree 2006). In France, some rural areas show positive demographic trends that cannot be explained 
by urban spillover alone (Pistre 2012). Another example is visits to places perceived as the countryside, which now serve as recreation areas for urbanites (Le Caro 2007; Mormont 1987; Øian 2013).

Spatial planning has also been conceptualized and organized according to the type of geographical area. Its conception of the relationship of inhabitants to nature has undergone deep changes. The concepts of urban park and garden city emerged at the end of the nineteenth century (Smith 2008), but these concepts were neglected later on. As of the mid-twentieth century, attention shifted to areas outside cities through suburbanization, as well as through areas designed for the pleasure of urbanites, assuming they would travel to such areas to enjoy the presence of nature (Attali 2017; Mormont 1987). The beginning of the twenty-first century has shown yet another turn: urban planning once again puts emphasis on the relationship to nature in cities through the preservation of open natural areas in and around city centers (Banzo 2009; Tzoulas and James 2010). It is assumed that the presence of green spaces within proximity to urbanites' homes enhances their quality of life and health (Bourdeau-Lepage 2017; Bourdeau-Lepage and Vidal 2013; Cadieux 2011; Lange et al. 2008; Schipperijn et al. 2010). Open natural areas are now an integral part of urban planning (Kowarik 2013; Schipperijn et al. 2010). The term "nature" creates a wide range of images (Cadieux 2011; Emelianoff 2016), allowing several forms of connections with it in densely urbanized areas. Urban planning now considers the city as a place for many types of nature: ornamental trees and forests, pocket gardens and urban agriculture, public parks and wildlife corridors, "green" roofs and urban green trams, etc. In keeping with these trends, the connection with nature in urban settings is now one of the main subjects of human-nature connection studies (Ives et al. 2017).

Some authors, however, suggest that the presence of nature in cities is not generally accepted since nature is related to the wilderness, to the absence of people (Kalaora 2001) and of human management (Colléony et al. 2017; Kaplan and Austin 2004). Nature could seem less true, more factitious when present in cities (Glatron et al. 2012). The idea that urbanites could travel to natural places out of town (Attali 2017; Mormont 1987) should still be considered: people can value their contact with nature in different ways depending on the types of areas (Buijs et al. 2009; Colléony et al. 2017; Glatron et al. 2012; Mathieu 2017). They can also select the places where they seek a contact with nature according to such types. For example, Mathieu (2017) showed that some people limit their connection to nature to emblematic natural areas such as national parks.

The examination of the literature shows some lack of consideration for the geographical dimension of people's connections to nature, as already pointed out. On the one hand, the focus on the presence of nature in cities is not balanced with a complete examination of people's contemporary perceptions of the presence of nature in the different area categories. Do people consider that certain types of areas are more suitable for a contact with nature? On the other, there is a lack of empirical studies of the diversity of places frequented to find a contact with nature. The empirical study presented in the following section allowed us to explore these two geographical dimensions of the connection to nature.

\section{Material and methods}

The survey sample

The survey took place in Occitanie, a French region offering a wide variety of geographical contexts: big urban areas (Toulouse is the fourth largest city in France), hills and mountains. This survey was dedicated to understanding the diversity of lifestyles in this region, and its sampling was designed to maximize this diversity. It was organized at two levels. First, we took the diversity of areas where people live into account. Second, we considered the diversity of people living in each selected area. This sampling technique allowed us to explore the difference in the connection to nature between people living in cities and people living outside them, while taking the differences between different people's views into account in each area.

We selected 13 municipalities (Fig. 1) reflecting the types identified by the functional classification developed by the French National Statistics Agency (INSEE) (INSEE 2014; Creusat and Moret-Chevillet 2015). We thus selected municipalities at the center of big and medium-size urban poles, suburban municipalities and municipalities located in hilly or mountainous areas, described by INSEE as "isolated 


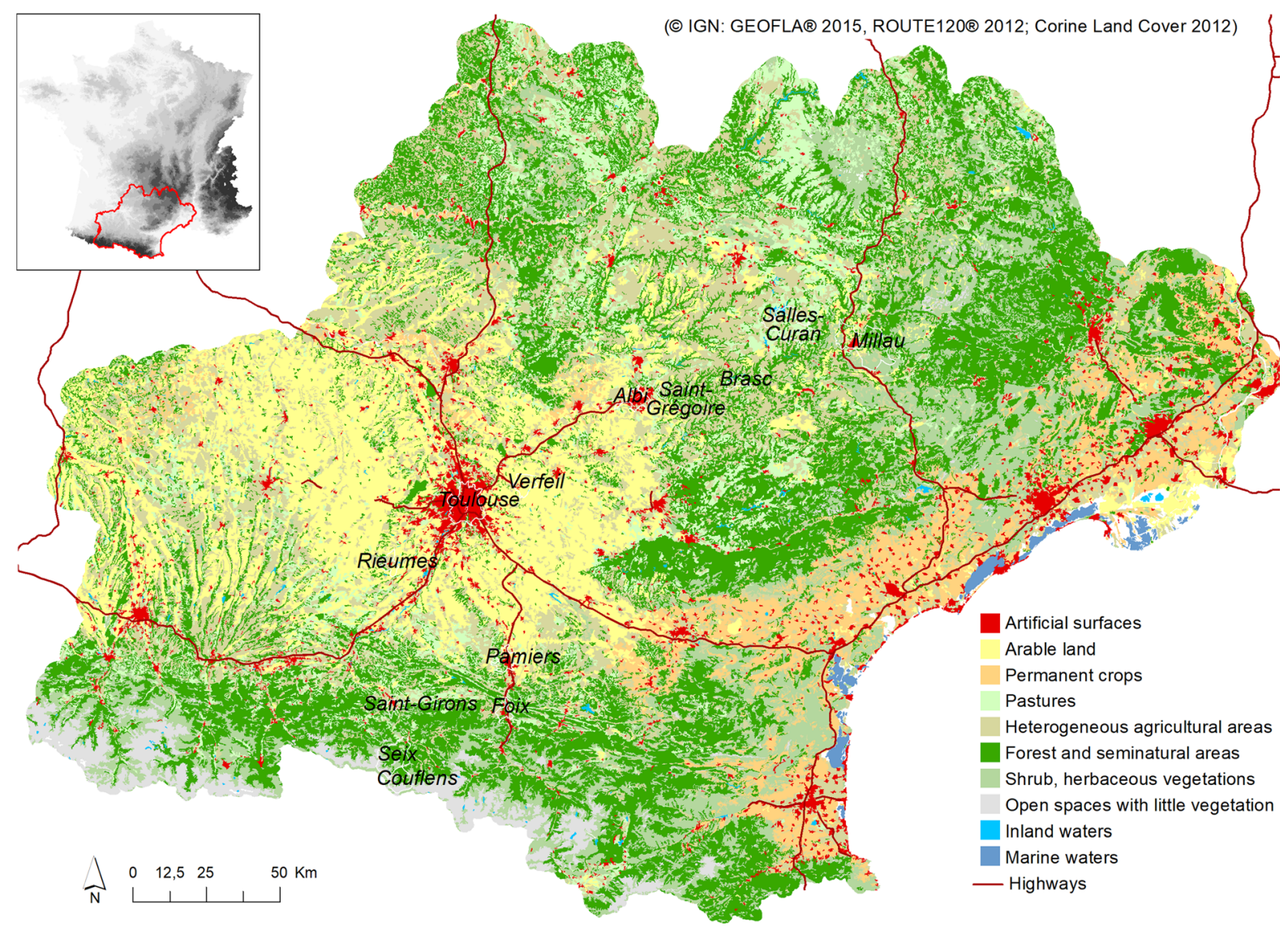

Fig. 1 Location of the 13 municipalities in the Corine Land Cover description of land used in the Occitanie region. Inset: Location of Occitanie on the altitude map of France

municipalities outside the influence of urban poles" (referred to as "non-urban" in the rest of the text) ${ }^{1}$.

\footnotetext{
1 To characterize French urbanization, INSEE now proposes two types of classifications (Creusat and Moret-Chevillet 2015). The morphological classification is based on population density on $1-\mathrm{km}^{2}$ grid cells, and follows the Eurostat degree of urbanization methodology. The functional classification considers an urban pole to be the municipality or the group of municipalities that include a continuous built-up area of at least 2000 inhabitants and a concentration of more than 1500 jobs. For each urban pole, the surrounding municipalities, where $40 \%$ of the active population consists of commuters, form the suburban zone of the urban poles. If the urban pole provides at least 10,000 jobs, the urban unit is considered as "big". If the number of jobs ranges between 5000 and 9999, the urban unit is considered as "medium". Otherwise, it is considered to be small. In the "isolated municipalities outside the influence of the urban poles", the active population does not commute within the same range to urban poles. This functional classification is close to the Eurostat Larger Urban Zone classification. We refer to this last classification because it differentiates suburban municipalities from rural ones.
}

According to Vallès (2018), demographic growth from 2006 to 2016 in France mainly took place in the big urban poles and in the suburban municipalities surrounding them. The demographic features of the selected municipalities follow this trend. The cities at the center of big urban poles, such as Toulouse and Albi, have recently undergone an increase in population, but the strongest increase concerns their suburban municipalities, resulting in a high percentage of young people in the population. In the cities at the center of medium-size urban poles, such as Foix and SaintGirons, the demography is more stable and the population is aging. Non-urban municipalities have lost or are still losing inhabitants, their vacant homes being converted into vacation homes, especially in tourist areas (Table 1).

To constitute the sample of interviewees in these municipalities, we first addressed key actors who had good knowledge of the local population (mayor, 
Table 1 Demographic features of the 13 municipalities in the survey

\begin{tabular}{|c|c|c|c|c|c|c|c|}
\hline \multirow[t]{2}{*}{ Municipalities } & \multirow[t]{2}{*}{$N^{\mathrm{a}}$} & \multirow{2}{*}{$\begin{array}{l}\text { Population density } \\
2014\end{array}$} & \multirow{2}{*}{$\begin{array}{l}\text { Population } \\
2014\end{array}$} & \multicolumn{2}{|c|}{ Rates of population change } & \multirow{2}{*}{$\begin{array}{l}\text { Aging index }{ }^{b} \\
2014\end{array}$} & \multirow{2}{*}{$\begin{array}{l}\text { Secondary dwelling } \\
2014(\%)\end{array}$} \\
\hline & & & & $1975 / 1990(\%)$ & $1990 / 2014(\%)$ & & \\
\hline \multicolumn{8}{|c|}{ Municipality at the center of a big urban pole } \\
\hline Toulouse & 3 & 3942 & 474,246 & -4 & 32 & 59 & 2 \\
\hline Albi & 6 & 1119 & 51,794 & 1 & 11 & 112 & 2 \\
\hline Pamiers & 2 & 339 & 16,499 & -9 & 27 & 89 & 1 \\
\hline \multicolumn{8}{|c|}{ Municipality at the center of a medium-size urban pole } \\
\hline Foix & 5 & 503 & 10,226 & 4 & 3 & 115 & 4 \\
\hline Saint-Girons & 5 & 329 & 6745 & -19 & 2 & 149 & 5 \\
\hline Millau & 4 & 131 & 22,936 & -1 & 5 & 123 & 6 \\
\hline \multicolumn{8}{|c|}{ Suburb of a big urban pole } \\
\hline Rieumes & 2 & 114 & 3593 & 16 & 49 & 77 & 2 \\
\hline Verfeil & 3 & 84 & 3509 & 31 & 55 & 62 & 1 \\
\hline Saint-Grégoire & 4 & 39 & 512 & 1 & 67 & 48 & 8 \\
\hline \multicolumn{8}{|l|}{ Non-urban } \\
\hline Salles-Curan & 5 & 11 & 1091 & -14 & -15 & 170 & 44 \\
\hline Seix & 4 & 8 & 726 & -20 & -10 & 151 & 65 \\
\hline Brasc & 5 & 8 & 172 & -30 & -9 & 152 & 35 \\
\hline Couflens & 4 & 1 & 82 & -81 & 17 & 162 & 82 \\
\hline
\end{tabular}

The municipalities are presented according to the spatial categories of INSEE

${ }^{a} \mathrm{~N}$ : number of interviews in the municipality. ${ }^{\mathrm{b}}$ The aging index is the ratio of the over-65 population to the under-20. Sources: INSEE, Population census for 19751990 and 2014; Observatoire des territoires for the Aging Index

municipal councilor, city clerk, local development officer, business association member). They described the social and professional diversity of the municipal population to us. In the selection of the interviewees, we respected this diversity. In many cases, the informant suggested an initial list of three people, which we completed either by the snowballing technique or by chance encounter. We interviewed 52 people, 21 men and 31 women, whose ages ranged from 25 to 55 -years-old, residing in these 13 municipalities. The interviews took place in their homes as well as in public places such as cafés. In some cases, their spouses were present. The sample was composed of 15 public employees (teachers, librarian, city officials, municipal workers, etc.), seven employees (salespeople, NGO workers), seven small business owners (shops, cafés, garage), five professional artists, five CEOs or managers of companies or organizations, five farmers, one logger, four domestic workers, two self-employed people (a nurse, a computer consultant) and one person without a professional activity. Thirty- five lived in detached houses and 17 in apartments. Thirty-nine owned their own home or lived on a family-owned property, ten rented their places of residence (no information was collected on this point in three of the cases). This low proportion of tenants compared to the national one might be due to the inclusion of several municipalities where the population density is low. All in all, our sample represents medium occupational categories in various kinds of professions, and might be unbalanced in its representation of unemployed people.

The interviews

The interview guidelines concerned four intertwined topics summarizing the person's lifestyle: the residence and the residential trajectory; his or her mobility pattern for working, shopping and leisure activities; if he or she categorized the place where he or she lived as urban, rural or other; and the person's perception and connection to nature. On this last topic, we asked the 
interviewees a general question about their relationship to nature: "Can you tell us about your relationship with nature?" If needed, the follow-up question was: "Do you sometimes go to natural areas?" Like Colléony et al. (2017), we considered that a visit to a natural place could be considered as a proxy of connecting to nature.

These questions were vague in order to let the people give them their own content. A large majority of the interviewees were eager to discuss the topic: 40 answered the questions and 32 used the term or discussed the importance of their connection to nature in other parts of the interview, for example, in relation to their residence, their leisure activities, or the differences they observed between cities and other areas. We used all the quotes alluding to nature in the interviews. The term was neither used nor discussed in only one case. Depending on the interviewee, the term "nature" could refer to several things, including the elements (the air, the seasons, high altitudes, the silence, the tide, the outdoors), vegetation (a plant, plants in general, trees or a specific tree, grass), animals (animals in general, birds, butterflies, the Pyrenean chamois, etc.), and landscapes (wide open spaces, Mediterranean or more humid landscapes, mountains).

The mean interview length was $1 \mathrm{~h}$. We recorded the interviews and transcribed them, except for one refusal where we only took notes.

Qualitative analysis

As mentioned before, the connection with nature can take different forms, implying material practices and/ or discursive representations (Ives et al. 2017; Øian 2013; Zylstra et al. 2014). In the interviews, we focused on the quotes alluding to "nature". We identified as "perceptions" the general discourses on nature mentioning its presence in a type of area. We distinguished them from material "practices" when contacts with nature are described as activities or experiences embodied in some specific place (Fig. 2).

Our objective was to identify general patterns of the connection with nature in terms of perceptions and practices. In qualitative analysis, thematic analysis is the common tool to track such general patterns (Fox 2004). Nevertheless, this technique has been severely criticized for its blurring of the singular discourses and of their inner logic (Demazière and Dubar 2004) because it organizes the analysis by theme, across all the interviews, instead of interview-by-interview. To limit this issue, we conducted two thematic analyses but supplemented them with an analysis of the differences in answers of the interviewees. The first thematic analysis was dedicated to the perception of the presence of nature in different categories of areas, and the other to the specific places where practices are carried out to connect with nature. In parallel, we kept track of each interviewee in the thematic analyses. This allowed us, first, to weight the diversity of answers in order to measure how general the emerging patterns were and, second, to take the specificity of each interviewee into account, considering the fact that different people can have different ways and different places to connect to nature (Mathieu 2017). Given the quantity of data collected and in order to facilitate the navigation between the thematic analyses and the specificity of each interview, we analyzed the data with the qualitative data analysis software, NVivo 11.

The description of the results mirrors this hybrid strategy by displaying the general findings at the scale of the whole survey and, for some results, by presenting the response of each of the 52 interviewees. In the same way, the illustrative quotes serve to offer a deeper comprehension of the content of some of the sub-codes, in addition to highlighting the differences between respondents.

\section{Coding practices and perceptions}

In the thematic analyses (Fox 2004) of the material, we maintained a qualitative and inductive approach to the interviews, either taking the interviewees' own categories into account, or the way they used the categories embedded in the questions. For each theme, the coding was "emergent" and hierarchical (Ayache and Dumez 2011). To do this, we attempted to identify the oppositions that organize the discourses (Demazière and Dubar 2004), and used these oppositions to create the sub-codes that fit the diversity of answers or opinions expressed.

The first code contains the 191 quotes of 46 interviewees expressing and, in some cases, explaining the presence of nature in different categories of areas (six did not make any comments about the presence of nature in any area category). We organized this code according to the categories of areas 


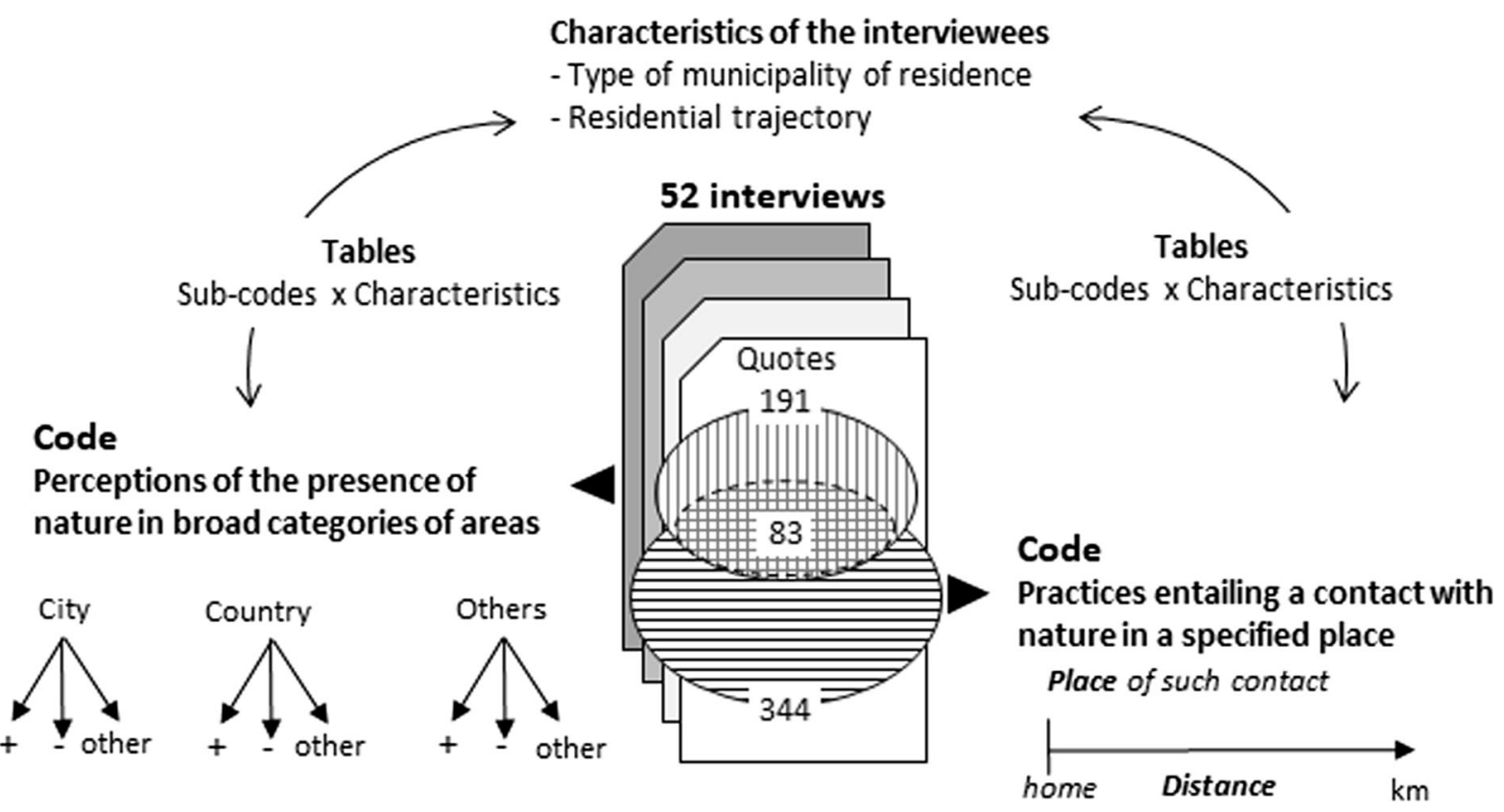

Fig. 2 Overview of the qualitative analysis strategy adopted

mentioned in the quotes. Some were already present in our questions, such as "the city" (la ville) or "the countryside" (la campagne), but the interviewees used other broad categories such as "the mountains" (la montagne) or "the sea" or "the seaside" (la mer). The abundance of references to the mountains in the interviews might be due to their presence in the region, and particularly of the Pyrenees, often quoted and visible from far away (Fig. 1). The perceived links between the categories mobilized and nature were classified by creating sub-codes concerning the presence or the absence of nature in each category. When relevant, we created other sub-codes to take other types of relationships, such as proximity, into account.

The second code encompasses the 344 quotes describing the contact with nature made by 49 of the interviewees and presented as current or recent (three interviewees did not mention any practice where they feel a contact with nature). Eighty-three of these quotes are also found under the first code, when the specific place where a contact with nature is mentioned is related to a generic area category. These experiences are diverse and might refer to nature as a setting for the residence (seeing the mountain from home, for example) or leisure activities (walks, sports as well as hunting and fishing), as the purpose of visiting places, but also to feelings of immersion in nature and of the dominance of nature. We considered the place of such practices and coded the quotes according to the distance from the residence in order to evaluate the importance of the proximity to natural places. Since the interviews were conducted in the municipality of residence, there was a bias toward it in the description. Nevertheless, the reference to the residence also emerged from the material, with some interviewees stressing that they did not have to go outside their home to feel their connection with nature. The definition of the different thresholds was empirical, corresponding to differences the interviewees made between usual practices and more occasional ones. Such usual practices encompassed the activities in the municipality of residence or in the municipalities surrounding it, corresponding to a distance of less than $10 \mathrm{~km}$, which defined our first threshold. The second one, at $50 \mathrm{~km}$ from the residence, corresponds to activities they described as taking more time or involving a short trip by car. Beyond $50 \mathrm{~km}$, the activities are described as less common. In the majority of the cases, the interviewees located or named the places, making it possible to evaluate the distance from the residence on Google Maps. Some interviewees referred to a family home, frequently visited and the object of a deep attachment, as a place 
to connect to nature. We kept track of these houses in the sub-coding.

\section{Considering the personal characteristics of each interviewee}

To discuss the diversity in the practices or perceptions expressed, we considered several characteristics of each interviewee. We considered the type of municipality of residence according to the official functional classification (INSEE 2014). We also considered the residential trajectory, which emerged as a relevant category from the interviews, since some of the interviewees explained that they had moved in order to live closer to nature. We differentiated the 20 people who lived in the municipality where they grew up: a few had never moved; others returned after their studies or after several years of working elsewhere, sometimes abroad. The 32 people who moved gave two main reasons for their relocation: the proximity to jobs and/or services ( 21 people), and the proximity to open natural areas (11 people). The proportion of the latter is greater in non-urban municipalities, but some of them also moved to suburban municipalities or medium-size cities in mountainous areas. Five of them moved to a place they already knew because they had spent vacations there during their childhood (in a family home, for example, or in a touristic location).

\section{Results}

Perceived presence of nature in the different categories of areas

The majority of the quotes about the presence of nature concerned the city and the countryside. It was also in these areas that disagreements between interviewees appeared, as well as in some of their discourses when a second quote nuanced a former one. The number of people who consider that the city can be a place where nature can be felt is similar to the number of people who consider the opposite (Table 2). In both cases, the majority (13 and 12, respectively) lives in big or medium-size city centers. The first ones link the presence of nature in the city to specific urban open areas such as parks, riverbanks and creeks where they can take a walk or jog. They also recognize the presence of natural elements in the city, such as old trees or wild vegetation growth and, in certain cities close to the mountains, air quality (lack of pollution) and the view of the mountains. A few mention the differences between cities in this respect, in favor of small ones where green areas are closer and there is less traffic pollution. The smallest cities in our sampling, such as Saint-Girons and Millau, are even considered as belonging to the rural area, for the first one, and as a hybrid between city and nature, for the second. Sixteen out of the 19 people who find nature in the city nevertheless consider other categories of areas in which they can experience a contact with nature (Table 3). A majority of them associate nature more deeply with the other areas, like the countryside, the mountains or the seaside. When they explain these differences between areas, they link them to the degree of urbanization, highlighting the crafting of nature by man in cities (see quote in Table 2 and quote in Sect. 3.2 for examples). For some, the difference is linked to the quality of the bodily experience they can have: sensations are less acute in cities, especially of the natural cycles (seasons, tides). In the other categories of areas considered, the crafting of nature is less well perceived. Among the people who consider that nature is not present in the city, a few explained this opinion along the same line of thought: natural elements (parks, trees) can be found in cities, but not nature itself.

In our sample, the countryside is the category most often mentioned as a natural place. Among those who disagree, some make a clear difference between manmade countryside and the wilder areas (see quote in Table 2 for an example). Several interviewees point out the changes in the countryside due to the conventional, if not industrial, forms of agriculture, to explain why the countryside cannot be considered as a natural place. For instance, in one interview, a controversial project of an industrial pigsty in a rural municipality casts doubts about whether the place can still be considered as natural:

— "Would you say that [in this municipality] we are in a natural area? Predominantly natural? - More or less, let's say yes. [...] Natural areas... [speaking to a third party:] Didn't you talk about the [industrial] pigsty [project]?" [Engineer, 41-45 years-old, non-urban municipality] 
Table 2 Number of interviews $(\mathrm{N})$ containing quotes expressing a link between nature and the categories of areas and examples

\begin{tabular}{|c|c|c|}
\hline $\begin{array}{l}\text { Quotes expressing the } \\
\text { following: }\end{array}$ & $N$ & Examples \\
\hline You can find nature in cities & 18 & $\begin{array}{l}\text { "In a city, trees are needed, not only grass. That would allow people to sit down. Nature } \\
\text { makes that possible." }\end{array}$ \\
\hline $\begin{array}{l}\text { You can find nature close to } \\
\text { cities }\end{array}$ & 11 & $\begin{array}{l}\text { "[in cities] there are natural places, parks, but that's not really nature. When I want to escape } \\
\text { from it all, quickly and close by, because I need to, I drive up to [a municipality nearby]" }\end{array}$ \\
\hline $\begin{array}{l}\text { You can't find (true) nature in } \\
\text { cities }\end{array}$ & 19 & $\begin{array}{l}\text { "Paris, I loved it because I like cultural activities, but I wanted to leave the place because of } \\
\text { the lack of nature." }\end{array}$ \\
\hline $\begin{array}{l}\text { The countryside is a natural } \\
\text { place }\end{array}$ & 34 & $\begin{array}{l}\text { "I like nature, I like the countryside. I'm like a fish out of water in the city. My goal is } \\
\text { therefore to live in the countryside!" }\end{array}$ \\
\hline $\begin{array}{l}\text { The countryside is not (really) a } \\
\text { natural place }\end{array}$ & 10 & $\begin{array}{l}\text { "To me, it's wilderness that matters. Parks depress me. I can't stand them. And in the } \\
\text { countryside where you only find plowed land and rape fields as far as the eye can see, It } \\
\text { makes me want to shoot myself." }\end{array}$ \\
\hline The mountain is a natural place & 18 & "Yes, I like nature well enough but I couldn't live in the heart of the mountains." \\
\hline The seaside is a natural place & 7 & "I like this natural sea environment. I really love it!" \\
\hline None & 6 & \\
\hline
\end{tabular}

In contrast, mountain and seaside areas are presented as the categories of space linked to real nature. For instance, one person said that the Pyrenees are the "real natural nature" (la vraie nature naturelle) [Environmental educator, 26-30 years-old, suburban municipality]. Another one, quoted in Table 2, speaks about the "wild nature" (la nature sauvage) she can find in the mountains, and not in the cultivated countryside. Some of our data suggest that for this area category, the perception of the presence of nature is also linked to a low degree of human presence and human management. "Wild means there are no structures, nothing built, nothing planned... for human beings". [Farmer, 45-50 years-old, non-urban municipality].

For part of our interviewees, there is no strict opposition between city and nature (Table 2). Nevertheless, even in these cases, the idea remains of a gradient of nature along the different categories of areas. Its main contrast is between cities and, among them, the big ones, and the countryside, perceived as a more natural area (Table 3). Our data also show negative judgments on the presence of nature in cities in the same proportion. According to these judgments, the presence of natural elements in cities is not enough to consider that nature is present. To a lesser degree, our data show that the presence of nature in the countryside is also questioned. In both cases, the rationale, when expressed, emphasized the human presence and intensive human management to explain why nature itself cannot be found. The changes in the countryside toward more intensive agriculture seem to strengthen the distinction between areas perceived as wild, represented by the Pyrenees or, for some, by the seaside, and the other area categories. As already mentioned about the traditional opposition between city and nature, the image of mastering nature, or not (Blanc 1997a), seems to explain the differences made between the different area categories. In the city, elements of nature are perceived and appreciated, but seen as "prefabricated" nature. In the countryside, intensive management by farmers is also seen as a control of the natural elements. In the other areas identified by the interviewees, such as the mountain or the seaside, nature is perceived as not being intensively managed and as being dominant. This first analysis was based on the general comments made about the presence of nature in broad categories of areas. The second one will focus on the place where people go to find such contact.

Places where to connect to nature and their distances from home

The residence in itself is an important place to connect to nature for 31 of our interviewees (Fig. 3), confirming other findings (Cadieux 2011). They describe different types of connections, e.g., a visual 
Table 3 Identification of the presence of nature in the different categories of areas for the 52 interviewees (Each column represents one interviewee. Gray indicate that interviewees acknowledged the presence of nature in the category of area)

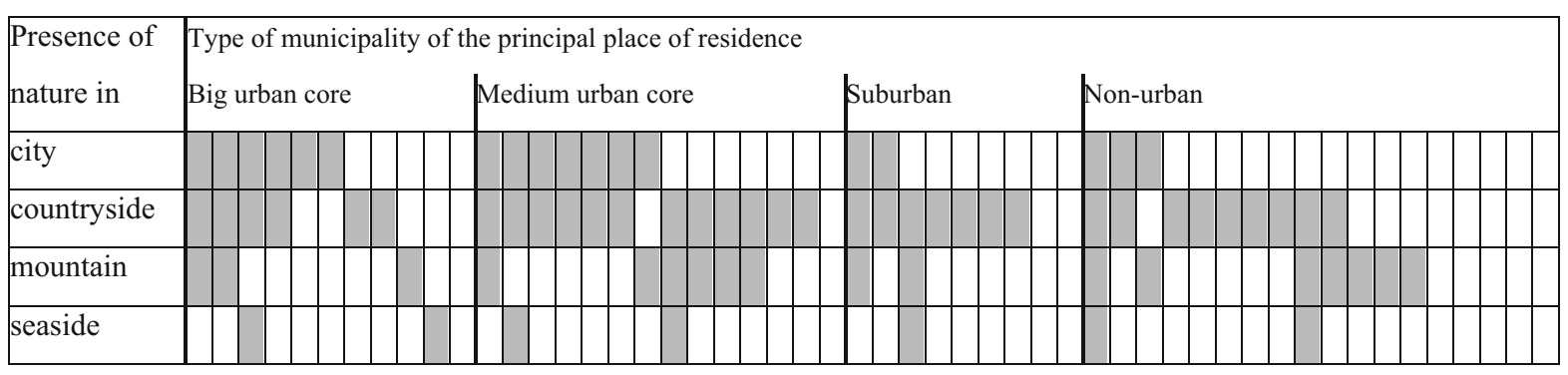

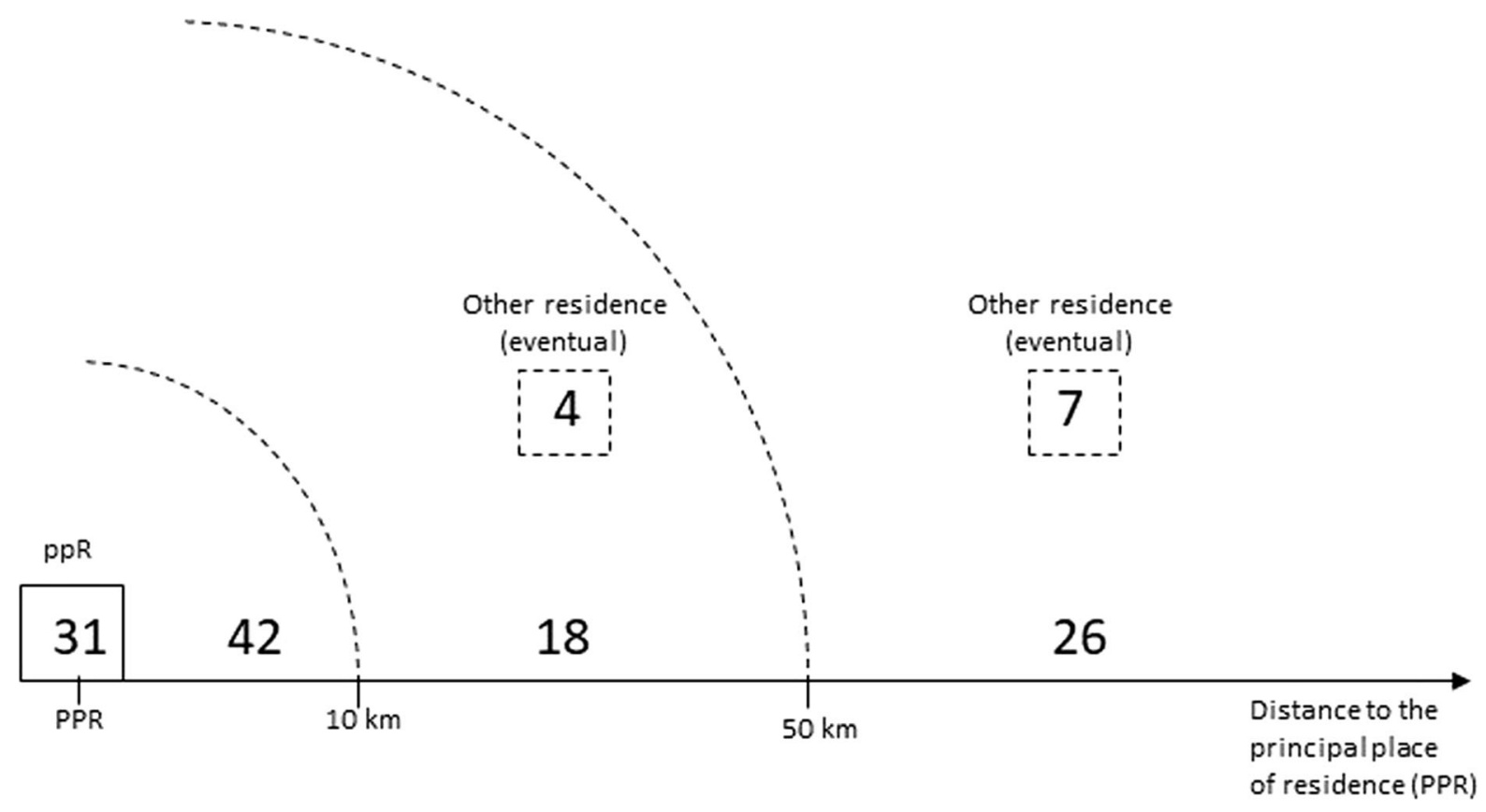

Fig. 3 Locations of the places to connect to nature according to the estimated distance from home for 49 of the interviewees. In 11 cases, these places were another regularly visited (personal or family) residence

experience such as looking out over open landscapes identified as the countryside, or at mountains from a building, or hearing birds instead of cars. It can also be the sensation of breathing in clean air, even in certain cities, or of feeling the wind. Having a garden can also be an important way to connect to nature, be it a private garden or a community garden in collective housing. The proportion of people who expressed a contact with nature at home is within a similar range in all types of municipalities (from 55 to 64\%). Living inside a city, even a big one, does not prevent some people from finding a contact with nature at home. The residential trajectory seems to be more discriminant, with the people who had moved to be closer to nature mentioning connections to nature from their home in a higher proportion (73\%), compared to people born in the municipality where they live $(50 \%)$ or having moved there for professional reasons or to be closer to services (62\%) (Table 4).

This might suggest that people who move to be closer to nature expect to enjoy nature from home. However, the principal residence is not the only place where 11 of our interviewees live. They all regularly spend time in another house, from twice a month to 
Table 4 Mention of the place of residence as a place to connect to nature (R) according to the type of municipality and to the residential trajectory of the interviewees

\begin{tabular}{|c|c|c|c|c|c|c|c|c|c|c|}
\hline \multicolumn{11}{|c|}{ Type of municipality of the principal place of residence } \\
\hline \multicolumn{2}{|c|}{ Big urban core } & \multicolumn{3}{|c|}{ Medium urban core } & \multicolumn{3}{|c|}{ Suburban } & \multicolumn{3}{|c|}{ Non urban } \\
\hline born & job & borr & job & op & born & job & op & born & job & open \\
\hline \begin{tabular}{|l|l|}
$R$ & $R$ \\
\end{tabular} & \begin{tabular}{|l|l|l|l}
$R$ & $R$ & $R$ & $R$ \\
\end{tabular} & $\mathrm{R}$ & \begin{tabular}{|l|l|l|l|l|l|}
$R$ & $R$ & $R$ & $R$ & $R$ & $R$ \\
\end{tabular} & \begin{tabular}{|l|l|}
$R$ & $R$ \\
\end{tabular} & \begin{tabular}{l|l|l}
$R$ & $R$ & $R$ \\
\end{tabular} & & \begin{tabular}{|l|l|}
$R$ & $R$ \\
\end{tabular} & \begin{tabular}{|l|l|l|l}
$R$ & $R$ & $R$ & $R$ \\
\end{tabular} & \begin{tabular}{|l|l|l|}
$R$ & $R$ & $R$ \\
\end{tabular} & \begin{tabular}{l|l|l|l}
$\mathrm{R}$ & $\mathrm{R}$ & $\mathrm{R}$ & $\mathrm{R}$ \\
\end{tabular} \\
\hline
\end{tabular}

Each column represents one interviewee. "born" = lives in the municipality where she/he grew up; "job" = changed municipality to be closer to jobs or services, "op." or "open" = said that she/he changed municipality seeking open natural areas as a living place

every two months. It is often a family home belonging to their parents (principal or vacation home of the latter) or, in two cases, inherited from them. In only one case, such a place is not linked to the family but to the collective practice of fishing and hunting in mountainous areas from a shared cabin. These houses are described as privileged places to connect with nature because of their isolation, as expressed by an interviewee: "It is a peaceful, calm, quiet place where nature reigns supreme." [Association manager, 51-55 years-old, big city]. These places can be located in mountainous areas (a house in a village or an isolated former barn or a shepherd's hut), in the countryside or by the sea. These houses are presented as places where the connection with nature was experienced during childhood, but also where it can be transmitted to the next generation. The following quotes serve to illustrate these two points:

"The mountains. I love that too. It's... that's, I think, places where we spend our childhood, our youth, we never forget it. So, I regularly go back to it and I can see that my children like it as well." [Local representative, 46-50 years-old, non-urban municipality].

“- - It's an old sheepfold that my dad restored.

— And when you're there, you feel like...

- You can recharge your batteries. Yes. Returning to the roots in a way, and the omnipresence of nature... And isolated from the world, because there's no network for the cell phone... Yes, nature and water. We go there regularly [with my daughter]. I think it's important for her because we have such a peaceful time there." [Designer, 31-35 years-old, big city].
However, the interviewees also find a contact with nature in places other than their residences during outdoor activities at different distances from their home. A majority of them (42/52) describe different types of outings close to their home, in the same municipality or in surrounding ones. Urbanites can use open areas in the city to walk or jog on a path around the river, or to go to a park alone or with their children. Some prefer to drive a few minutes to find a more open landscape. People living outside of cities can also do the same: leave their home to walk their dogs in suburban forests, enjoy a lake during summer, fish or cycle, make short hikes in the surrounding mountains in the evening, or find a point of view to observe wild animals. These activities are presented as frequent and easy to do at the end of a day's work. Longer and more extensive activities may imply going further away, from 10 to $50 \mathrm{~km}$, like hiking for a few hours or a few days, making a bigger cycling tour than usual, hunting or fishing. Extended mobility is generally reserved for weekend and vacation activities but may also include the habitual shopping trip for people living far away from the city, which could be the occasion to contemplate the natural landscape during the long drive.

When looking at all the places where each interviewee experienced a contact with nature (Table 5), 43 interviewees out of 52 described practices carried out in several locations, for example, the residence, but also places nearby and at a great distance from their home during their vacation. On the contrary, people spoke of their residence as the only place where they experience a contact with nature in only three interviews. The three were farmers, lived on their farms, and did not mention leisure activities or vacations during the interviews. In their case, the farm 
Table 5 Distance between the main residence and the place of contact with nature for the 52 interviewees

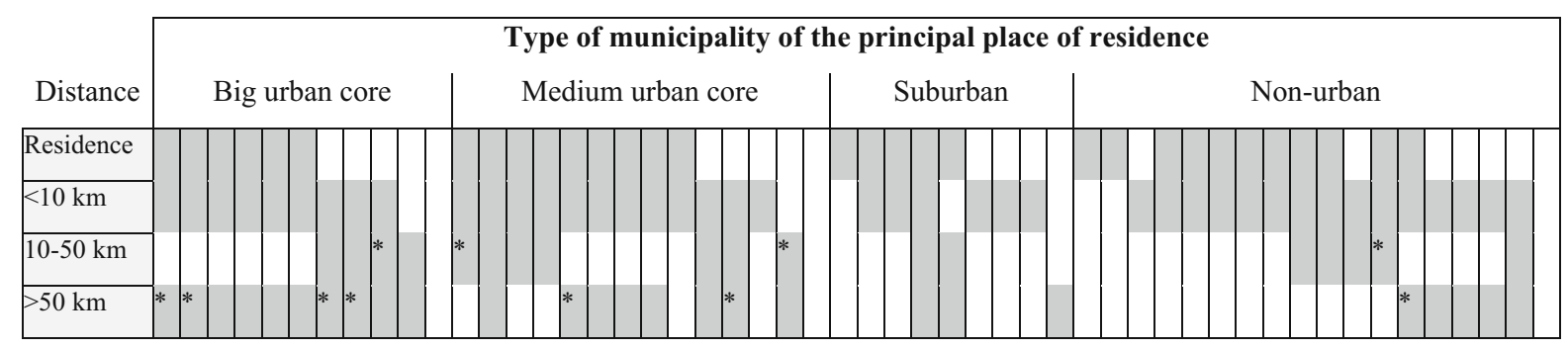

Each column represents one interviewee. Gray areas represent the location of the practice, according to the coding* indicates second home

itself is the place mentioned for being in nature, as illustrated by this quote: "Oh yes, yes! Being outside, out in nature... We're doing what we like most. We go outside. We say: Let's go! Let's install fences." [Farmer, 31-40 years-old, suburban municipality].

The diversity of places where nature is experienced may be more frequent for people living in urban centers due to more frequent visits to places at a great distance from their home, mainly during summer vacation. Mention of a residence presented as a second home or at least a regular place to stay is also more frequent among the urban interviewees. The case of a middle-aged artist, born and living in a building in a big city, illustrates such a trend where the experience of nature is divided between her home, outings close to home and visits to a family residence at a greater distance. In her building, the management decided to create a collective garden, and she expresses its importance for her: "Growing vegetables in a garden, for instance. It's new to me. And I always have... always lived with plants. I cannot live without plants!" She also speaks of her experience in several parks or with different natural areas such as flower beds in the city during her professional activity, as well as her walks: "I discovered some plants. There is an area with plants, I took some of them with me ... I looked it up to know what it was because it bothered me that I didn't know that plant. I just love that! [...] Nature, I really see it in the city. I appreciate it, I love it and I need it." Nevertheless, she expresses her preference to connect with nature in another residence, that of her father who retired to the countryside. "If I don't go to the sheepfold for a long time, I miss it a lot. [...] I also need not to see billboards, not to hear traffic... I need to breathe. To see many, many, many trees. To see wetlands. To see wild plants and not those we put on roundabouts, those that appear from one day to the next already in blossom. I need to see the buds on the trees. I need to smell. [...] We live in a prefabricated nature when we're in a city and I need to see nature... the most natural possible, I would say. That's what I really need. And it is such a pleasure! I like going to those places for their nature." [Artist, 46-50 yearsold, big city].

The people we interviewed generally experience a connection with nature in several places. The residence and the places close by are widely mentioned in relation to such experiences, even for urban residents. Nevertheless, access to a second home in a non-urban setting is described as a richer experience of nature. These results confirm the importance of taking various forms of mobility but also of residence into account (Adamiak et al. 2017) to better understand the patterns to connect with nature.

\section{Discussion and conclusion}

The use of the term "nature" and the narratives about a contact with it were quite common in our interviews, confirming that such a contact is an important part of people's lifestyles today (Mathieu 2017). To understand how such a contact is geographically organized, we considered both how people linked the presence of nature and the categories of areas they mentioned, and the places they frequented to find nature. The first analysis shows that lay discourses on nature might be changing. The opposition between city and nature is fading in some discourses. The presence of nature in the countryside is questioned, and new categories of 
areas are linked to the figure of the wilderness, like in other countries (Smith 2008). The contemporary insistence on nature in the city has filtered down into people's discourses, especially those of urbanites. Even so, traditional views on the unequal presence of nature in the different types of areas (Berque 2011; Blanc 1997a, b; Tjallingii 2000) are still part of the perceptions. Depending on the interviewee, natural elements can be found in every category of area, but "true nature" or "wild nature" cannot be experienced in highly managed areas such as cities, nor in the intensively cultivated countryside. Our data show several images of nature according to the intensity of human management and how the independence of nature is valorized (Buijs et al. 2009). These different images are localized according to the categories of areas perceived by people.

Considering the place where people experience a contact with nature, our second analysis highlights the residence as such a place (Cadieux 2011), as well as the importance of taking the mobility patterns that organize the contact with nature into account. More traditional ways of thinking of and seeking the presence of nature has not disappeared from people's habits. It might be by relocating the residence or having a second home, or by visiting distant open areas in non-urban settings.

These two analyses converge in showing that people contrast several areas and several places to organize their thinking of and their contact with nature. While a large part of the current literature focuses on the relationship with nature in the city (Bourdeau-Lepage 2017; Cadieux 2011; Kowarik 2013), our study allowed a more complete geographical understanding of the way people experience such a contact with nature, a point not yet fully addressed (Klaniecki et al. 2018).

Our study contrasts with more quantitative approaches that assess the preferences for one type of landscape or another in large surveys. As is generally the case with qualitative studies that rely on interviews, it addressed only a small sample. For the genericity of our findings, we tried to maximize the variety of people we interviewed by choosing a diversity of municipalities of residence. The resulting sample encompasses medium occupational categories in different types of professions. Our methodological choice facilitated the discourses on the residence when little was said about practices that could be developed, for example, from the place of work. The methodological choice of interviewing middle-aged people turned out to be relevant since several people expressed the importance of family transmission and childhood experiences to learn to appreciate the connection with nature, as already reported by Colléony et al. (2017) and Sahuc (2010). For the stage of life of our respondents, we collected data on both their childhood experiences and the transmission of their experience of nature to their children. A study targeting younger people's experiences of nature and of the ways that they built them could expand this point. Our empirical findings point to a relative individualization of the connection with nature (Cadieux 2011), highlighting the importance of the home and the extended family. People experiencing several weeks of home confinement during the Covid19 pandemic, and the various suggestions as to how to take advantage of and enjoy the presence of nature from home, like, for example, recognizing the variety of birds visible outside of the window, might confirm the importance of these findings. A study of the balance between personal and collective or public places such as public forests or parks in terms of experiencing nature could make it possible to better understand and evaluate this point.

The interviewees who spoke about their experience of nature in places they considered to be wild, such as mountains or the seaside, emphasized the fact that they can forget about human management and feel the force of nature. In contrast, natural areas in cities were often presented as a product of the human crafting of nature and of the mastering of natural cycles. This opposition reveals the distinction and the different valuation of several "figures of nature" (Kowalik 2013). These results suggest that a reflection on the type and esthetics of natural areas in cities could be a valid step toward a more satisfying experience with nature in urban settings. Nevertheless, the present focus in the literature on the proximity of natural areas to urban dwellers' residences may underestimate both the importance of the residence itself as a place of contact with nature and the mobility patterns that make people feel closer to nature, such as relocation, multiple residences, short outings and longer trips.

Acknowledgments This work was carried out within the framework of the French LABEX SMS with the reference ANR11-LABX-0066. It was part of the project "Les dynamiques 
territoriales entre sphères urbaine et rurale. We are grateful to $\mathrm{L}$. Barthe, J. Bessière, F. Cavaille, F. Escaffre, C. Eychenne, C. Jebeili, F. Laumière, M. Sibertin-Blanc and F. Taulelle for their participation in the interviews, and to Olivier Bories and Patricia Panegos for previous discussions and exchanges of ideas. We are very thankful to Denis Blamont to help us revise the manuscript.

Author contributions All authors contributed to the study conception and design. Material preparation and data collection were organized by MG. Data analysis was performed by ID and MG. The first draft of the manuscript was written by ID and MG and all authors commented on previous versions of the manuscript. All authors read and approved the final manuscript.

\section{Compliance with ethical standards}

Conflict of interest The authors declare that they have no conflict of interest.

\section{References}

Adamiak, C., Pitkänen, K., \& Lehtonen, O. (2017). Seasonal residence and counterurbanization: the role of second homes in population redistribution in Finland. GeoJournal, $82,1035-1050$.

Arnould, P., Le Lay, Y.-F., Dodane, C., \& Méliani, I. (2011). La nature en ville : l'improbable biodiversité. Géographie, Economie, Société, 13, 45-68.

Attali, M. (2017). La France redessinée? Espaces et territoires de loisirs dans la seconde moitié des années 1960. French Historical Studies, 40(4), 651-674.

Ayache, M., \& Dumez, H. (2011). Le codage dans la recherche qualitative une nouvelle perspective? Le Libellio d'Aegis, $7(2), 33-46$.

Banzo, M. (2009). L'espace ouvert pour une nouvelle urbanité. Habilitation thesis, Bordeaux 3 University.

Berque, A. (2011). Le rural, le sauvage, l'urbain. Etudes Rurales, 187(1), 51-61.

Blanc, N. (1997a). La place de la nature dans la géographie urbaine. Géographes Associés, 20, 63-69.

Blanc, M. (1997b). La ruralité : diversité des approches. Economie Rurale, 242, 5-12.

Bourdeau-Lepage, L., \& Vidal, R. (2013). Nature urbaine en débat : à quelle demande sociale répond la nature en ville ? In A.Torre (Ed.), Nature et agriculture pour la ville (pp. 293-308). Demeter

Bourdeau-Lepage, L. (2017). Ville et nature, vers une nouvelle alliance? In Ph. Hamman (Ed.), Ruralité, nature et environnement : entre savoirs et imaginaires (pp. 359-374). ERES.

Buijs, A. E., Elands, B. H. M., \& Langers, F. (2009). No wilderness for immigrants: Cultural differences in images of nature and landscape preferences. Landscape and Urban Planning, 91, 113-123.

Cadieux, K. C. (2011). Competing discourses of nature in exurbia. GeoJournal, 76, 341-363.
Colléony, A., Prévot, A.-C., Jalme, M., \& Clayton, S. (2017). What kind of landscape management can counteract the extinction of experience? Landscape and Urban Planning, 159, 23-31.

Creusat, J., \& Morat-Chevillet, H. (2015). La hiérarchie des villes en France métropolitaine sur trente ans: stabilité globale et reclassements. In L. Brière \& S. Vugdalic (Eds.), La France et ses territoires (pp. 23-38). Paris: Insee, Insee Références.

Demazière, D., \& Dubar, C. (2004). Analyser les entretiens biographiques. L'exemple des récits d'insertion.

Emelianoff, C. (2016). Quartiers durables. Un nouvel imaginaire de la nature ? In A. Choné, I. Hajek, \& P. Hamman (Ed.), Guide des humanités environnementales (pp. 545-555). Villeneuve d'Ascq: Septentrion.

Fox, N. J. (2004). Qualitative Data Analysis. University of Sheffield.

Glatron, S., Grésillon, E., \& Blanc, N. (2012). Les trames vertes pour les citadins : une appropriation contrastée à Marseille. Développement Durable et Territoires. https://doi. org/10.4000/developpementdurable.9297

Hess, G., \& Salomon Cavin, J. (2015). Le Parc naturel urbain en Suisse : une utopie ? Approche philosophique pour dépasser l'opposition ville/nature. VertigO, 15(1).

Halfacree, K. (2006). From dropping out to leading on? British counter-cultural back-to-the-land in a changing rurality. Progress in Human Geography, 30(3), 309-336.

Insee. (2014). Trente ans de démographie. Le rôle structurant du bassin parisien et des très grandes aires urbaines. Insee Première, 1483, 1-4.

Ives, C. D., Giusti, M., Fischer, J., Abson, D. J., Klaniecki, K., Dorninger, C., Laudan, J., Barthel, S., Abernethy, P., Martín-López, B., Raymond, C. M., Kendal, D., \& von Wehrden, H. (2017). Human-nature connection: a multidisciplinary review. Current Opinion in Environmental Sustainability, 26-27, 106-113.

Jessop, B., Brenner, N., \& Jones, M. (2008). Theorizing sociospatial relations. Environment and Planning D: Society and Space, 26, 389-401.

Kalaora, B. (2001). A la conquête de la pleine nature. Ethnologie Française, 31(4), 591-597.

Kaplan, R., \& Austin, M. E. (2004). Out in the country: Sprawl and the quest for nature nearby. Landscape and Urban Planning, 69 (2), 235-243.

Khew, J. Y. T., Yokohari, M., \& Toshinori, T. (2014). Public perceptions of nature and landscape preference in Singapore. Human Ecology, 42, 979-988.

Klaniecki, K., Leventon, J., \& Abson, D. J. (2018). Humannature connectedness as a 'treatment' for pro-environmental behavior: Making the case for spatial considerations. Sustainability Science, 13, 1375-1388.

Kowarik, I. (2013). Cities and wilderness. A new perspective. International Journal of Wilderness, 19(3), 32-36.

Lange, E., Hehl-Lange, S., \& Brewer, M. J. (2008). Scenariovisualization for the assessment of perceived green space qualities at the urban-rural fringe. Journal of Environmental Management, 89 (3), 245-256.

Le Caro, Y. (2007). Les loisirs en espace agricole. Presses Universitaires de Rennes, Rennes. 
Mathieu, N. (2017). La nature et le rural. In Ph. Hamman (Ed.), Ruralité, nature et environnement. Entre savoirs et imaginaires (pp. 61-89). Erès, Toulouse.

Mormont, M. (1987). Rural nature and urban natures. Sociologia Ruralis, 27(1), 3-20.

Øian, H. (2013). Wilderness tourism and the moralities of commitment: Hunting and angling as modes of engaging with the natures and animals of rural landscapes in Norway. Journal of Rural Studies, 32, 177-185.

Pickel Chevalier, S. (2014). L'occident face à la nature. A la confluence des sciences, de la philosophie et des arts. Editions Le Cavalier Bleu, Paris.

Pistre, P. (2012). Le renouveau des campagnes françaises. $\mathrm{PhD}$ in Geography of Paris 7 University.

Sahuc, Ph. (2010). Chemins périurbains : aménités vécues et enjeux réels. Natures Sciences Sociétés, 18, 147-157.

Schipperijn, J., Ekholm, O., Stigsdotter, U. K., Toftager, M., Bentsen, P., Kamper-Jørgensen, F., \& Randrup, T. B. (2010). Factors influencing the use of green space: Results from a Danish national representative survey. Landscape and Urban Planning, 95, 130-137.

Smith, S. J. (2008). The evolving relationship between open space preservation and local planning practice. Journal of Planning History, 7, 91-112.
Tjallingii, S. P. (2000). Ecology on the edge: Landscape and ecology between town and country. Landscape and Urban Planning, 48, 103-119.

Tzoulas, K., \& James, P. (2010). Peoples' use of, and concerns about, green space networks: A case study of Birchwood, Warrington New Town, UK. Urban Forestry \& Urban Greening, 9, 121-128.

United Nations (2018). World urbanization prospects: The 2018 revision. Key facts. Retrieved from https://population.un. org/wup/Publications/Files/WUP2018-KeyFacts.pdf

Vallès, V. (2018). Entre 2011 et 2016, les grandes aires urbaines portent la croissance démographique française. Insee Focus, 138, 8 p.

Zylstra, M. J., Knight, A. T., Esler, K. J., \& Le Grange, L. L. L. (2014). Connectedness as a core conservation concern: An interdisciplinary review of theory and a call for practice. Springer Science Reviews, 2, 119-143.

Publisher's Note Springer Nature remains neutral with regard to jurisdictional claims in published maps and institutional affiliations. 